\title{
KONSELING TRAUMATIK: SEBUAH STRATEGI GUNA MEREDUKSI DAMPAK PSIKOLOGIS KORBAN BENCANA ALAM
}

\author{
Hayatul Khairul Rahmat ${ }^{1 *}$, Desi Alawiyah ${ }^{2}$ \\ ${ }^{1}$ Universitas Pertahanan, Bogor \\ Komplek Indonesian Peace and Security Center, Sentul, Citeureup, Bogor, Indonesia \\ ${ }^{2}$ Institut Agama Islam Muhammadiyah Sinjai, Sinjai \\ Jalan Sultan Hasanuddin Nomor 2, Balangnipa, , Sinjai, Sulawesi Selatan, Indonesia \\ *Corresponding Author: hayatul.rahmat@idu.ac.id, Telepon: +6281268928954
}

\begin{abstract}
Abstrak
Tulisan ini mencoba untuk membahas konseling traumatik sebagai sebuah strategi untuk mereduksi dampak psikologis korban bencana alam. Indonesia adalah negara yang akan mengalami bencana yang dapat dilihat berdasarkan data dari Badan Nasional Penanggulangan Bencana pada tahun 2019 yang disediakan 3.721 peristiwa bencana. Bencana yang terjadi akan menimbulkan dampak psikologis maupun dampak nonpsikologis. Penulisan ini menggunakan pendekatan studi literatur. Temuan dalam penelitian ini adalah (1) konseling traumatik merupakan proses memberi makna bagi klien yang mengalami trauma dan memberi makna pula bagi konselor yang membantu mengatasi trauma kliennya; (2) dampak psikologis dari bencana alam dapat diketahui berdasarkan tiga faktor yaitu faktor pra bencana, faktor saat bencana, dan faktor pasca bencana; dan (3) dalam implementasi konseling traumatik dalam mereduksi dampak psikologis korban bencana alam menggunakan beberapa strategi dalam tiga tahap yaitu tahap awal konseling, tahap pertengahan konseling, dan tahap akhir konseling.
\end{abstract}

Kata Kunci: Konseling Traumatik, Dampak Psikologis, Bencana Alam, Strategi.

\begin{abstract}
This paper tried to discuss about traumatic counseling as a strategy to reduce the psychological impact of victims of natural disasters. Indonesia was a country that will experience a disaster that can be seen based on data from the National Disaster Management Agency in 2019 which provided 3,721 disaster events. Disasters that occur will have psychological and non-psychological impacts. This research used a literature study approach. The findings in this study are: (1) traumatic counseling is a process of giving meaning to clients who have experienced trauma and giving meaning to counselors who help overcome the trauma of their clients; (2) the psychological impact of natural disasters can be known based on three factors, namely pre-disaster factors, factors during disasters, and post-disaster factors; and (3) in implementing traumatic counseling in reducing the psychological impact of victims of natural disasters using several strategies in three stages, namely the initial stage of counseling, the middle stage of counseling, and the final stage of counseling.
\end{abstract}

Keywords: Traumatic Counseling, Psychological Impact, Natural Disaster, Strategy. 


\section{Pendahuluan}

Bencana menurut Undang-Undang Nomor 24 Tahun 2007 menjelaskan bahwa bencana adalah sebuah rangkaian kejadian yang mengganggu dan mengancam penghidupan dan kehidupan masyarakat sekitar yang disebabkan oleh faktor alam, non alam, atau faktor manusia yang menelan korban jiwa manusia, rusaknya lingkungan, kehilangan harta benda, dan dampak pada psikologis. Indonesia adalah negara yang rawan akan bencana alam. Kondisi tersebut membuat Indonesia dilanda oleh bencana alam yang datang silih berganti setiap tahunnya (Rahmat et al., 2020). Berdasarkan data yang dimiliki oleh Badan Nasional Penanggulangan Bencana Nasional (BNPB) menyebutkan bahwa selama tahun 2019 mulai dari 1 Januari 2019 sampai 23 Desember 2019 terdapat 3.721 kejadian bencana alam di seluruh Indonesia. Dari fenomena alam tersebut dapat membuktikan Indonesia adalah negara yang rawan akan bencana alam. Berikut adalah Gambar 1 yang menjelaskan data kejadian bencana pada tahun 2019:

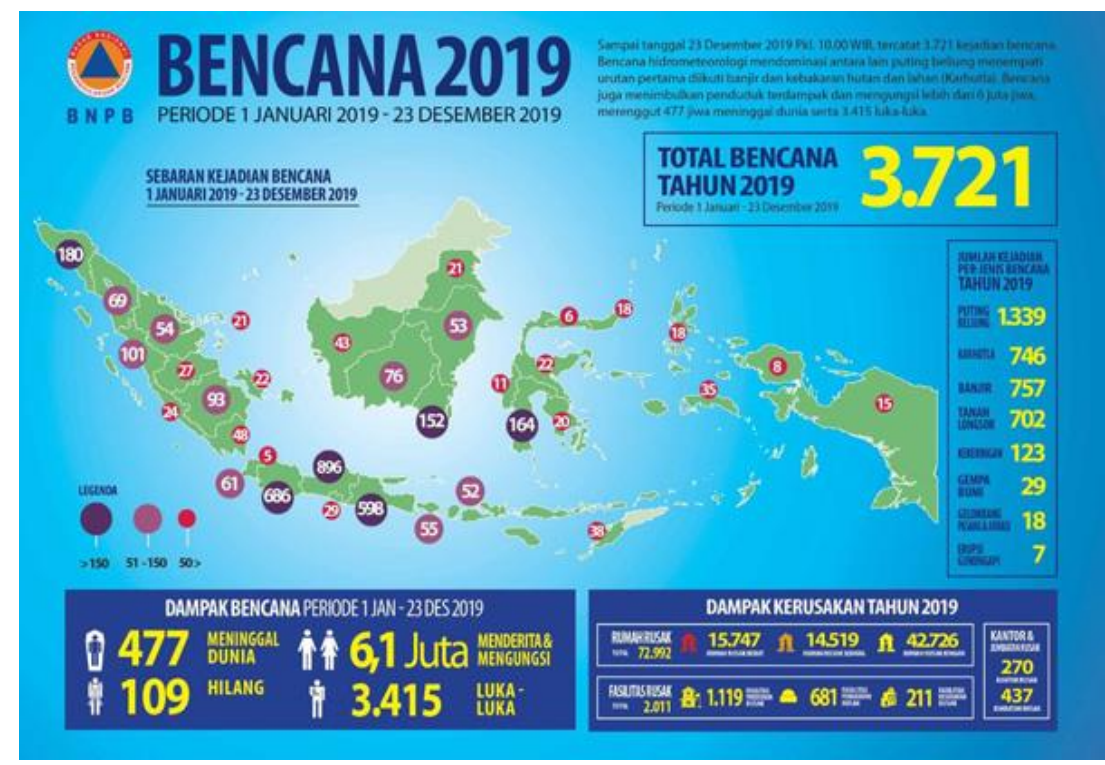

Gambar 1. Kejadian Bencana pada Tahun 2019

Berdasarkan Gambar 1, dapat dilihat data kejadian bencana pada tahun 2019 mencapai 3.721 kejadian bencana. Kejadian bencana yang terjadi tersebut dapat dilihat terjadi hampir di semua provinsi di Indonesia. Berbagai bencana alam yang datang silih berganti tersebut dipengaruhi karena Indonesia terletak di 
antara zona subduksi atau pertemuan tiga lempeng tektonik yang bertumbukan yaitu lempeng Indo-Australia, lempeng Eurasia, dan lempeng Pasifik. Ketika salah satu dari lempeng tersebut bergerak, maka akan terjadi gempa bumi, letusan gunung berapi, dan tsunami di Indonesia (CFE-DMHA, 2015). Selain itu, Indonesia juga terletak di jalur gempa bumi dan gunung berapi yang dinilai paling dahsyat oleh United States Geological Surveys (Utomo \& Minza, 2016). Jalur yang terkenal dengan nama Pasific Ring of Fire yang berbentang dari belahan bumi bagian barat tepatnya di Chile, kemudian melewati Jepang dan Asia Tenggara (Israel, 2010).

Dalam al-Quran disebutkan bahwa Allah SWT melarang manusia untuk berbuat kerusakan ( $f a s a d$ ) yang diisyaratkan dalam 50 (lima puluh) ayat al-Quran dengan penyebutkan kata fasad kurang lebih sebanyak 53 kali (Aly, 1997). Beberapa contoh perbuatan kerusakan ( fasad) adalah pengrusakan tumbuhan, generasi manusia, dan keharmonisan lingkungan (Rahmat, 2018). Berikut Allah SWT menjelaskan dalam Q.S. al-Baqarah ayat 205 yang berbunyi:

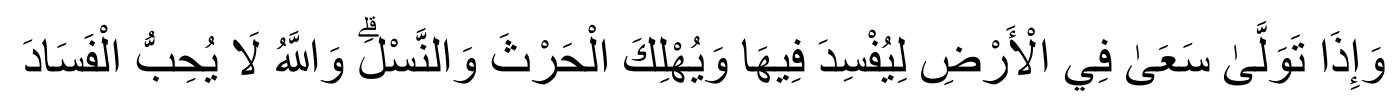

Terjemahan:

"Dan apabila ia berpaling (dari kamu), ia berjalan di bumi untuk mengadakan kerusakan padanya, dan merusak tanam-tanaman dan binatang ternak, dan Allah tidak menyukai kebinasaan." (Q.S. al-Baqarah/2: 205).

Tidak dapat dipungkiri dengan terjadinya bercana alam menimbulkan banyak sekali dampak negatif bagi kehidupan masyarakat, di antaranya timbulnya korban jiwa yang tidak sedikit, hilangnya harta benda, kerusakan lingkungan, dan terganggunya fungsi psikologis para korban bencana alam (Utomo \& Minza, 2016). Penanganan terhadap dampak negatif yang ditimbulkan haruslah dilakukan sesegera mungkin setelah bencana terjadi. Semakin cepat penanganan dilakukan maka dampak negatif semakin depat pula dapat direduksi serta dapat mempercepat pula proses pemulihan fungsi psikologis korban bencana alam. 
Dalam menangani dampak negatif yang ditimbulkan oleh bencana alam bukanlah suatu perkara yang mudah tetapi butuh berbagai pihak yang berkolaborasi untuk menanganinya. Begitu juga bencana memiliki akibat yang cukup fatal yaitu dampak psikologis. Dampak psikologis dipengaruhi oleh interaksi perubahan atau gangguan fisik, psikologi, situasi sosial, dan masalah yang bersifat material (Rahmat et al., 2018). Akibat dari bahaya trauma ini diperlukan suatu solusi untuk mengurangi dampak psikologis pada korban bencana.

Trauma berasal dari bahasa Yunani yang berarti luka. Kata trauma digunakan untuk menggambarkan kejadian ataupun situasi yang dialami oleh korban. Kejadian atau pengalaman traumatik akan dihayati secara berbeda-beda antara individu yang satu dengan lainnya sehingga setiap orang akan mengalami reaksi yang berbeda-beda pula pada saat menghadapi kejadian yang traumatik. Adapun ciri-ciri trauma adalah a) Disebabkan oleh kejadian dahsyat yang mengguncang di luar rencana dan kemauan kita; (b) Kejadian itu sudah berlalu; (c) Terjadi mekanisme psikofisis artinya kalau tidak melawan maka saya akan binasa; d) Sensitif terhadap stimulus yang menyerupai kejadian asli (Triantoro \& Saputra, 2009).

Kondisi trauma biasanya berawal dari keadaan stress yang mendalam dan berlanjut yang tidak dapat diatasi sendiri oleh individu yang mengalaminya. Sejauh mana trauma tersebut berkembang, bagaimana sifat atau jenisnya. Bila keadaan trauma dalam jangka panjang, maka itu merupakan suatu akumulasi dari peristiwa atau pengalaman buruk yang memilukan yang kemudian konsekuensinya menjadi suatu bebat psikologis yang amat berat dan mempersulit diri seseorang dalam proses penyesuaian diri, akan menghambat perkembangan emosi dan sosial individu dalam berbagai aspek perilaku dan sikap, seperti dalam hal proses pendidikan maupun pemenuhan kebutuhan-kebutuhan individu lainnya secara luas.

Melihat kondisi yang demikian, maka diperlukanlah suatu layanan konseling pada individu yang mengalami trauma-trauma maupun dampak psikologis agar tidak sampai belebihan seperti stress dan depresi yang berdampak 
mereka tidak dapat melakukan aktivitas sehari-hari seperti biasanya. Dalam melakukan konseling traumatik, keberadaan konsep deteksi awal akan menjadi hal penting untuk dipahami dan diperhatikan oleh pemberi bantuan sehingga tergambar berbagai sifat atau jenis trauma yang diderita oleh korban seperti trauma ringan, sedang, dan berat. Namun, tidak semua peristiwa yang dialami manusia bermuara kepada trauma. Biasanya kejadian dan pengalaman yang buruk, mengerikan, menakutkan, atau mengancam keberadaan individu yang bersangkutan, maka kondisi ini akan berisiko memunculkan trauma.

Metode yang digunakan oleh konselor dalam menangani konseli juga berbeda-beda, hal ini wajar karena setiap orang berbeda-beda dalam memahami orang lain. Dalam pendekatannya, ada yang menggunakan pendekatan persuasif dan ada juga dengan pendekatan intensif. Dalam menumbuhkan konseli pasca trauma pun tidak hanya dengan satu teknik atau strategi saja, namun harus mengglobal agar dalam menghadapi dan menyikapi konseli dengan tepat sesuai dengan yang diharapkan. Oleh karena itu, penelitian ini bertujuan untuk membahas konseling traumatik sebagai sebuah strategi guna mereduksi dampak psikologis pada korban bencana alam.

\section{Metode Penelitian}

Penulisan ini disusun menggunakan metode kepustakaan (library research). Library research ini dilakukan dengan mengumpulkan berbagai referensi bacaan yang relevan dengan permasalahan yang diteliti, kemudian dilakukan pemahaman cara teliti dan careful sehingga mendapatkan sebuah temuan-temuan penelitian (Zed, 2003). Penulis melakukan literature study secara mendalam untuk mendukung penelitian ini.

\section{Hasil dan Pembahasan}

\subsection{Konseptualisasi Konseling Traumatik: Sebuah Uraian Ringkas}

Konseling adalah praktik yang dijalankan sesuai dengan seperangkat aturan atau pedoman yang disusun oleh lembaga konseling profesioanl dan sesuai dengan kode etik, nilai-nilai, pengalaman, pandangan, perasaan, dan kemampuan 
klien dalam menentukan nasibnya sendiri (Geldard \& Geldard, 2004). Konseling merupakan suatu proses pemberian bantuan (give helping) yang bersifat teraputik yang diarahkan untuk mengubah sikap dan perilaku konseli, yang dilaksanakan secara person to person yaitu antara konseli dan konselor dengan menggunakan teknik wawancara sehingga diharapkan dapat mengentaskan permasalahan yang dialami oleh konseli.

Menurut Corney (dalam Pickett, 1998), trauma berasal dari Bahasa Yunani yang dapat diartikan luka. Kata trauma digunakan untuk menggambarkan kejadian atau situasi yang dialami oleh korban. Kejadian atau pengalaman traumatik pun akan dihayati secara berbeda-beda oleh setiap individu, sehingga setiap orang akan memiliki reaksi yang berbda pula dalam menghadapi setiap peristiwa traumatik. Oleh karena itu, menjadi suatu hal yang wajar ketika seseorang mengalami ketakutan baik secara fisik maupun emosional sebagai suatu reaksi stres atas kejadian traumatik tersebut. Kadang kala efek ini baru terjadi setelah beberapa jam, hari, atau bahkan berminggu-minggu. Respon individual pada umumnya yang terjadi adalah perasaan takut, tidak berdaya, atau merasa ngeri. Demikian pula cara individu menghadapi krisis tersebut akan bergantung pada pengalaman dan sejarah masa lalunya. Adapun indikator seseorang mengalami trauma adalah dibayangi oleh peristiwa traumatis, berpikir negatif, merasa tidak berdaya, emosional, mengisolasi diri, merasa harapan masa depan rendah (Afnibar, 2012).

Menurut Prawirohardjo (2010) melihat trauma sebagai pengalaman yang tiba-tiba, mengejutkan, dan meninggalkan bekas atau kesan yang mendalam pada jiwa seseorang yang mengalaminya. Menurut Pickett (1998), ada dua simtom yang dialami oleh individu yaitu (a) adanya ingatan terus-menerus tentang kejadian atau peristiwa tersebut, dan (2) mengalami mati rasa atau berkurangnya respon individu terhadap lingkungan. Kondisi ini selanjutnya akan mempengaruhi fungsi adaptif individu dengan lingkungan. Hal inilah menjadikan seseorang trauma yaitu muncul karena suatu peristiwa yang mengakibatkan terguncang jiwa seseorang sehingga sulit untuk mengendalikan dirinya sendiri. 
Sutirna (2013) menyebutkan konseling traumatik adalah upaya konselor untuk membantu klien yang mengalami trauma melalui proses hubungan pribadi sehingga klien dapat memahami diri sehubungan dengan masalah trauma yang dialaminya dan berusaha untuk mengatasinya sebaik mungkin. Tujuan konseling traumatik adalah untuk mengadakan perubahan perilaku pada klien sehignga memungkinkan hidupnya lebih produktif dan memuaskan, lebih menekankan pada pulihnya kembali klien pada keadaan sebelum trauma dan mampu menyesuaikan diri dengan keadaan lingkungan yang baru (Afnibar, 2012). Secara lebih spesifik, Murro dan Kottman (dalam Nurihsan, 2005) menjelaskan tujuan konseling traumatik adalah (a) berpikir realistis, bahwa trauma adalah bagian dari kehidupan; (b) memperoleh pengalaman tentang peristiwa dan situasi yang menimbulkan trauma; (c) memahami dan menerima perasaan yang berhubungan dengan trauma serta belajar keterampilan baru mengatasi trauma.

Konseling traumatik sangat berbeda dengan konseling biasa dilakukan oleh konselor, perbedaan ini terletak pada waktu, fokus, aktivitas, dan tujuan. Adapun konseling traumatik memerlukan waktu yang lebih lama dari konseling biasa, fokus pada trauma yang dirasakan sekarang, lebih banyak melibatkan orang banyak dalam membantu konseli dan yang paling aktif berperan adalah konselor (Tambusai, 2008). Adapun proses konseling traumatik adalah proses tengah berlangsung dan memberi makna bagi klien yang mengalami trauma dan memberi makna pula bagi konselor yang membantu mengatasi trauma kliennya.

\subsection{Dampak Psikologis Korban Bencana Alam}

Berbicara tentang bencana alam tentunya akan berdampak terhadap orang yang terdampak bencana alam tersebut. Salah satunya dampak psikologis. Dampak psikologis terdiri dari dua kata yaitu dampak dan psikologis. Dampak adalah pengaruh yang kuat yang menimbulkan akibat baik positif maupun negatif (Partanto, 1994). Kata psikologis merupakan kata sifat dari psikologi yang artinya kejiwaan. Menurut Irwanto (2002) menyebutkan bahwa psikologi jika diterjemahkan berarti ilmu yang mempelajari jiwa. Jadi dipahami bahwa dampak psikologis adalah dampak atau pengaruh yang kuat pada jiwa seseorang yang ditimbulkan oleh suatu penyebab yang dalam hal ini adalah bencana alam. 
Dampak akibat bencana alam secar psikis mencakup aspek emosi dan kognitif dari korban bencana alam. Aspek emosi terjadi dengan gejala-gejala seperti shock, rasa takut, sedih, dendam, rasa bersalah, malu, rasa tidak berdaya, kehilangan emosi seperti perasaan cinta, keintiman, kegembiraan atau perhatian pada kehidupan sehari-hari. Pada aspek kognitif juga mengalami perubahan seperti pikiran kacau, salah persepsi, menurunnya kemampuan untuk mengambil keputusan, daya konsentrasi dan daya ingat berkurang, dan menyalahkan dirinya sendiri.

Menurut Tomoko (2009) disebutkan bahwa dampak psikologis dari bencana alam dapat diketahui berdasarkan tiga faktor yaitu sebagai berikut:

1. Faktor pra bencana. Dampak psikologis pada faktor pra bencana ini dapat ditinjau dari beberapa faktor seperti jenis kelamin, usia dan pengalaman hidup, faktor budaya, ras, dan karakter etnis, sosial ekonomi, keluarga, serta tingkat kekuatan mental dan kepribadian.

2. Faktor bencana. Dampak psikologis dilihat dari faktor bencana ini maka dapat dilihat dari faktor seperti tingkat keterpaparan, ditinggal mati oleh sanak keluarga atau sahabat, diri sendiri atau keluarga terluna, merasakan ancaman keselamatan jiwa atau mengalami ketakutan yang luar biasa, mengalami situasi panik pada saat bencana, kehilangan harta benda dalam jumlah besar, pengalaman berpisah dari keluarga, pindah tempat tinggal akibat bencana, dan bencana menimpa seluruh komunitas.

3. Faktor pasca bencana. Dampak psikologis pasca bencana dapat diakibatkan oleh kegiatan tertentu dalam siklus kehidupan dan stres kronik pasca bencana yang terkait dengan kondisi psikiati korban bencana. Hal ini perlunya pemantauan jangka panjang oleh tenaga spesialis.

\subsection{Implementasi Konseling Traumatik dalam Mereduksi Dampak Psikologis}

\section{Korban Bencana Alam}

Sebagai mana proses konseling pada umumnya, proses dalam strategi konseling traumatik juga dibagi dalam tiga tahapan, yaitu tahap awal konseling, tahap pertengahan (tahap kerja), dan tahap akhir konseling (Nurihsan, 2005; 
Rahmat, 2019). Berikut adalah penjelasan dari strategi konseling traumatik dalam mereduksi dampak psikologis korban bencana alam:

1. Tahap awal konseling. Adapun pada tahap awal ini terjadi sejak konselor bertemu dengan konseli sehingga berjalanlah proses konseling dan menemukan defenisi masalah klien. Adapun yang dilakukan oleh konselor dalam proses konseling ini adalah sebagai berikut: (a) membangun hubungan konseling traumatik yang melibatkan klien yang mengalami trauma; (b) memperjelas dan mendefenisikan masalah trauma; (c) membuat penjajakan alternatif bantuan untuk mengatasi masalah trauma; dan (d) menegosiasikan kontrak.

2. Tahap pertengahan konseling. Berdasarkan kejelasan trauma klien yang disepakati pada tahap awal, kegiatan selanjutnya adalah mengkonfrontasikan pada: (a) penjelajahan trauma yang dialami klien; (b) bantuan apa yang akan diberikan berdasarkan penilaian kembali apa-apa yang telah dijelajahi tentang trauma klien.

3. Tahap akhir konseling. Pada tahap ini, konseling ditandai dengan beberapa hal berikut ini: (a) menurunnya kecemasan klien yang diketahui setelah konselor menanyakan keadaan kecemasannya; (b) adanya perubahan perilaku klien ke arah yang lebih positif, sehat, dan dinamik; (c) adanya tujuan hidup yang jelas di masa yang akan datang dengan program yang jelasp pula; (d) terjadinya perubahan sikap yang positif terhadap masalah yang dialaminya, dapat mengoreksi diri dan meniadakan sikap yang suka menyalahkan dunia luar seperti orang tua, teman, dan keadaan yang tidak menguntungkan.

\section{Simpulan}

Konseling traumatik sangat berbeda dengan konseling biasa dilakukan oleh konselor, perbedaan ini terletak pada waktu, fokus, aktivitas, dan tujuan. Konseling traumatik memerlukan waktu yang lebih lama dari konseling biasa, fokus pada trauma yang dirasakan sekarang, lebih banyak melibatkan orang banyak dalam membantu konseli dan yang paling aktif berperan adalah konselor. Adapun proses konseling traumatik adalah proses tengah berlangsung dan 
memberi makna bagi klien yang mengalami trauma dan memberi makna pula bagi konselor yang membantu mengatasi trauma kliennya. Sedangkan dampak psikologis dari bencana alam dapat diketahui berdasarkan tiga faktor yaitu faktor pra bencana, faktor saat bencana, dan faktor pasca bencana. Dalam implementasi konseling traumatik dalam mereduksi dampak psikologis korban bencana alam menggunakan beberapa strategi dalam tiga tahap yaitu tahap awal konseling, tahap pertengahan konseling, dan tahap akhir konseling..

\section{UCAPAN TERIMAKASIH}

Dalam kesempatan ini, kami mengucapkan banyak terima kasih kepada Program Studi Bimbingan Penyuluhan Islam, Fakultas Ushuluddin dan Komunikasi Islam, Institut Agama Islam Muhammadiyah Sinjai yang telah memberikan kesempatan kepada penulis untuk menerbitkan tulisan ini dalam Jurnal Mimbar : Media Intelektual Muslim dan Bimbingan Rohani.

\section{DAFTAR PUSTAKA}

Afnibar. (2012). Konseling Traumatik untuk Korban Gempa dan Resiliensi di Kalangan Masyarakat Minangkabau. Prosiding International Seminar and Workshop Post Traumatic Counseling, 46-56.

Aly, A. (1997). Ilmu Alamiah Dasar. Jakarta: Bumi Aksara.

CFE-DMHA. (2015). Indonesia Disaster Management Reference Handbook. Hawaii: Center for Excellence in Disaster Management and Humanitarian Assistance.

Geldard, K., \& Geldard, D. (2004). Membantu Memecahkan Masalah Orang Lain dengan Teknik Konseling. Yogyakarta: Pustaka Pelajar.

Irwanto. (2002). Psikologi Umum. Jakarta: Gramedia Pustaka Utama.

Israel, B. (2010). Indonesia's Explosive Geology Explained. Retrieved from http://www.livescience.com/8823-indonesia-explosive-geology-explained. html., diakses tanggal 5 Mei 2020.

Nurihsan, A. J. (2005). Strategi Layanan Bimbingan dan Konseling. Bandung: PT Refika Aditama.

Partanto, P. A. (1994). Kamus Ilmiah Populer. Surabaya: Arloka. 
Pickett, G. Y. (1998). Therapist in Distress: An Integrative Look at Burnout, Secondary Traumatic Stress and Vicarious Traumatization. United States: University of Missouri-St. Louis.

Prawirohardjo, S. (2010). Ilmu Kebidanan. Jakarta: Yayasan Bina Pustaka.

Rahmat, H. K. (2018). Traumatic Counseling Services As an Effort to Improve Resilience of Natural Disaster Victims. Proceeding The 1st International Conference on Islamic Guidance and Counseling 2018, 223-229.

Rahmat, H. K. (2019). Implementasi Strategi Layanan Bimbingan dan Konseling Komprehensif Bagi Siswa Tunanetra di MTs Yaketunis Yogyakarta. Hisbah: Jurnal Bimbingan Konseling dan Dakwah Islam, 16(1), 37-46.

Rahmat, H. K., Kasmi, \& Kurniadi, A. (2020). Integrasi dan Interkoneksi antara Pendidikan Kebencanaan dan Nilai-Nilai Qur'ani dalam Upaya Pengurangan Risiko Bencana di Sekolah Menengah Pertama. Prosiding Konferensi Integrasi Interkoneksi Islam dan Sains, 2, 455-461

Rahmat, H. K., Nurmalasari, E., \& Basri, A. S. H. (2018). Implementasi Konseling Krisis Terintegrasi Sufi Healing untuk Menangani Trauma Anak Usia Dini pada Situasi Krisis Pasca Bencana. Prosiding Seminar Nasional PIT ke- 5 Riset Kebencanaan IABI, 671-678.

Sutirna. (2013). Perkembangan dan Pertumbuhan Peserta Didik. Yogyakarta: Andi.

Tambusai, K. (2008). Trauma dan Konseling Traumatik. Bandung: Cita Pustaka Media Perintis.

Tomoko, O. (2009). E-Learning Disaster. Jakarta: Fakultas Ilmu Keperawatan Universitas Indonesia.

Triantoro, S., \& Saputra, N. E.. (2009). Manajemen Emosi: Sebuah Panduan Cerdas Bagaimana Mengelola Emosi Positif dalam Hidup Anda. Jakarta: Bumi Aksara.

Utomo, M. H., \& Minza, W. M. (2016). Perilaku Menolong Relawan Spontan Bencana Alam. Gadjah Mada Journal of Psychology, 2(1), 48-59.

Zed, M. (2003). Metode Penelitian Kepustakaan. Jakarta: Yayasan Obor Indonesia. 